\title{
What determines fuel selection in relation to exercise?
}

\author{
BY ARNE LINDHOLM \\ Department of Medicine and Surgery, Faculty of Veterinary Medicine, Swedish University of \\ Agricultural Sciences, Box 7018, 75007 Uppsala, Sweden
}

\section{La sélection de substrats dans le cadre de l'exercice physique}

\begin{abstract}
RÉSUMÉ
Au cours de l'exercice physique, de l'énergie est nécessaire dans la contraction des muscles, et la demande en énergie est un déterminant majeur pour la sélection des substrats. En fin de compte, c'est sous la forme d'ATP que l'énergie est utilisée par les muscles du squelette. Les principales substrats énergétiques disponibles pour les muscles dans l'exercice sont les glucides et les lipides. Le taux d'échange respiratoire (TER) est plus élevé à des intensités de travail plus élevées et la contribution des glucides au métabolisme total augmente comme une fonction de la vitesse proche ou supérieure à la $V_{\mathrm{O}_{2} \text { max }}$ où la plus grande partie de l'énergie est dérivée des glucides. Ainsi, l'intensité de l'exercice est un déterminant majeur de la sélection des substrats. Hurley et al. (1986) ont montré que le TER est moins élevé dans l'exercice sur des muscles entraînés que sur des muscles non-entraînés. Ils ont suggéré qu'une utilisation plus importante d'acides gras libres (AGL) dans le muscle entraîné est alimentée par une augmentation de la lipolyse des triacylglycérols du muscle. Il a été également démontré que la captation des $\mathrm{AGL}$ par le muscle dépend de la concentration des AGL dans le sang et de la déplétion des triacylglycerols dans les fibres du muscle. Une augmentation du métabolisme des lipides au cours de l'exercice prolongé a pour effet d'économiser le glycogène. Chez l'homme, il a été montré que le taux net d'utilisation du glycogène n'était pas lié à la concentration du glycogène du muscle avant l'exercice (Bangsbo et al. 1986). Il a également été démontré que chez l'homme la source de substrats pour le métabolisme de l'énergie peut être modifiée par le régime (Bergström et al. 1967). Chez le cheval, au cours de l'exercice sub-maximal, la proportion d'énergie produite à partir des glucides et des lipides peut être influencée par des manipulations du régime (Pagan et al. 1986). La composition du type de fibre, la capacité oxydative, la capillarisation, le nombre des mitochondries et la taille des fibres du muscle sont des facteurs importants pour la sélection des substrats au cours de l'exercice. Il a été démontré que les chevaux qui ont un très faible pourcentage de fibres de type IIA utilisaient moins de glycogène et produisaient moins de lactate que les chevaux qui ont un pourcentage élevé de fibres de type IIB. Les muscles qui montrent une capacité oxydative élevée contiennent souvent un pourcentage très faible de fibres de type IIB. Les chevaux de race d'élite ont un taux élevé de fibres IIA:IIB qui augmente avec l'entraînement. Chez le renne physiquement actif les trois types de fibres stockent les lipides et les réserves de glycogène et de triacylglycérols indiquent que les glucides aussi bien que les lipides sont importants pour la production de l'énergie. Étant donné que les zones de fibres sont réduites dans les fibres musculaires du renne, le nombre de
\end{abstract}


capillaires par $\mathrm{mm}^{2}$ est jusqu'à trois à quatre fois plus important que dans le muscle de l'homme, ce qui facilite le captation de l' $\mathrm{O}_{2}$ et des substrats d'origine sanguine comme le glucose et les AGL. Chez les animaux inactifs comme le porc, le profile métabolique du muscle est tout-à-fait différent.

Fuel selection during exercise is dependent on a variety of factors. Energy is needed in the process of muscle contraction and the energy fuels for exercising muscles are carbohydrate (CHO), fat and protein. However, ATP is the form of energy ultimately utilized by the skeletal muscles. Glycogen is the major storage form of $\mathrm{CHO}$ and triacylglycerol is the storage form of fats. Both forms function as energy reserves, whereas proteins can only supply energy at the expense of their structure and function. The intramuscular substrates glycogen and triacylglycerol may differ widely between individuals and between animals and can be greatly altered by diet and muscle fibre characteristics. The contribution of fat and CHO during exercise is primarily dependent on exercise intensity and duration (see Lindholm et al. 1974; Saltin \& Gollnick, 1988).

\section{EXERCISE INTENSITY}

The respiratory-exchange ratio (R-value) measured during exercise in humans and animals is higher at high work intensities. The relative contribution of $\mathrm{CHO}$ to total metabolism increases as a curvilinear function of exercise intensity at near or above $V_{\mathrm{O}_{2} \max }$ when nearly all energy may be derived from $\mathrm{CHO}$ oxidation, indicating a gradual decline in the relative role of fat for combustion. The intensity of exercise is, thus, one major determinant of fuel selection (Saltin \& Gollnick, 1988; Saltin \& Asstrand, 1993).

\section{Prolonged intense exercise}

During prolonged intense exercise when human subjects or animals can sustain work for several hours the oxidation of glucose and triacylglycerol derived from skeletal muscle is the primary pathway for the resynthesis of ATP. During light exercise it is mainly the slow-twitch type I and the fast-twitch type IIA fibres which are recruited. These fibres, which are highly oxidative, rich in mitochondria and highly capillarized have both glycogen and triacylglycerol as substrates. In human subjects a light workload is defined as that which demands $30-40 \%$ of an individual's $V_{\mathrm{O}_{2} \max }$ with a heart rate of about 110 beats/min. The R-value declines from 0.80 to 0.85 in the early phase of this exercise to just below 0.80 after several hours of exercise (Saltin \& Gollnick, 1988). Initially all the glycogen depletion occurs in the type I fibres (Costill et al. 1973). Gollnick et al. (1981) showed that the magnitude of the local glycogen stores of the muscle influences the uptake and use of blood-borne substrates, as well as determining endurance capacity during moderate-to-high-intensity exercise. The uptake of glucose from the blood to exercising muscle fibres gradually increases during prolonged exercise and the glucose uptake of the muscles is well matched by the release of glucose from the liver (Saltin \& Gollnick, 1988).

The importance of liver glycogen concentration for prolonged exercise was shown also in standard-bred trotters performing $4 \mathrm{~h}$ of trotting. At the end of the exercise period 
liver glycogen had decreased from 116 to $19 \mathrm{mmol} / \mathrm{kg}$ wet weight. The blood glucose declined gradually during the exercise period with one horse having a blood glucose concentration as low as $1.5 \mathrm{mmol} / \mathrm{l}$. The free fatty acids (FFA) increased gradually during the exercise period. The greatly reduced liver glycogen levels were accompanied by a decrease in blood glucose values.

In prolonged exercise of several hours duration the availability of substrates will be crucial. In a previously described study the FFA concentration gradually increased and after $4 \mathrm{~h}$ of trotting was about three times higher than that at rest (Lindholm et al . 1974).

Essén-Gustavsson et al. (1984) studied fibre types and substrate utilization in skeletal muscles of horses competing in endurance rides over 50 and $100 \mathrm{~km}$. This study showed that after the ride the type I fibres had utilized most glycogen and about $90 \%$ of these fibres were depleted of glycogen. Of the type IIA fibres $78 \%$ were medium stained on PAS staining and of the type IIB fibres only $16 \%$ had a low staining intensity. It was shown also that the best horses performing a 100 or $50 \mathrm{~km}$ race showed almost the same reduction in glycogen and triacylglycerol in the muscle. This finding indicates that the horses performing the longer race must have been relying to a greater extent on extramuscular energy sources, utilizing both $\mathrm{CHO}$ and lipids derived from both intraand extramuscular sources.

According to Björntorp (1991) the problem with lipid utilization during exercise is not the physical availability of fat as an energy source, but the ability to bring the lipid to the site of oxidation in the muscle. Muscles are able to change their preferred substrate for energy requirements from $\mathrm{CHO}$ to lipid, at least to some extent. However, the regulatory controls are poorly understood. The lipolytic process is stimulated by exercise and insulin concentrations are suppressed during exercise, inhibited by the sympathetic nervous system, thus facilitating lipid mobilization.

\section{Intense heavy exercise}

At intense heavy exercise demanding more than $90 \%$ of $V_{\mathrm{O}_{2} \max }$ the R-value is found to be about 0.95 for human subjects. During near maximal intense exercise the ATP store in the muscle fibres will be depleted quickly and ATP must be continually resynthesized. The anaerobic utilization of muscle phosphocreatine and glycogen will fuel muscle contraction during intense exercise. When the glycogen concentration in type II fibres is depleted the fall in ATP production cannot be compensated and there is a decrease in force generation.

The effect of draught-loaded exercise was studied using standard-bred horses (Gottlieb et al. 1989). Significantly reduced blood lactate concentrations after a standardized exercise speed-test were found after 4,8 and 11 weeks of training and muscle biopsy data showed an increased oxidative capacity of the muscle and an increased type IIA:IIB fibre value. The primary effect of draught-loaded training seems to be that an increasing part of the energy release may have occurred through oxidative processes.

The study also showed that glycogenolysis with lactate accumulation and phosphagen breakdown becomes more important when, with a draught load of $34 \mathrm{kp}$, the velocity of exercise increases. The metabolic response to draught-loaded exercise was affected by the speed, the draught resistance and the duration of work. 


\section{LACTATE METABOLISM AND GLYCOGEN RESYNTHESIS}

After intense exercise by human subjects most of the lactate produced is eliminated within $1 \mathrm{~h}$ (Hermansen \& Vaage, 1977). The major part of the lactate eliminated is converted to glycogen in the muscle fibres and only a minor part is oxidized (Hermansen \& Vaage, 1977). An increased rate of lactate elimination is observed if submaximal exercise is performed immediately after intense exercise, with high muscle lactate concentration (Hermansen \& Stensvold, 1972).

Nordheim \& Völlestad (1990) studied the influence of high lactate concentration after intense exercise on glycogen metabolism in active type I and inactive type II fibres when exercise was continued at $40 \% V_{\mathrm{O}_{2} \max }$ for $1 \mathrm{~h}$. They found that lactate decreased by 22.9 $\mathrm{mmol} / \mathrm{kg}$ wet weight after $20 \mathrm{~min}$ of low-intensity exercise, while glycogen remained unchanged in type I fibres and increased by $20 \mathrm{mmol} / \mathrm{kg}$ wet weight in type II fibres. During the next $40 \mathrm{~min}$ of low-intensity exercise glycogen decreased by $21 \mathrm{mmol} / \mathrm{kg}$ in the type I fibres but remained stable in the type II fibres. This study clearly shows that high lactate levels can serve to spare glycogen in active fibres and restore glycogen levels in inactive fibres.

\section{PROTEIN UTILIZATION DURING EXERCISE}

Amino acids may play a very significant role during endurance exercise as precursors for the synthesis of glucose to prevent hypoglycaemia. The most important function is possibly that protein might serve as a source of citric acid cycle intermediates for exercise metabolism (Dohm, 1986). Thus, protein may not play a direct role in exercise metabolism but it is an important source of precursors for glucose and of metabolites which are required for the oxidation of carbohydrates and fat.

Pösö et al. (1993) showed an increase in alanine in the muscle of horses performing a standardized exercise test on a treadmill. This study showed that nearly all the alanine could have been formed in the reaction catalysed by alanine aminotransferase ( $E C$ 2.6.1.2; ALAT). The other product of the reaction catalysed by ALAT, i.e. $\alpha$-ketoglutarate, is an intermediate of the citric acid cycle and, therefore, is of vital importance for the working oxidative muscle fibres.

\section{EFFECTS OF DIET}

The source of fuel for energy metabolism can be greatly altered by diet (Saltin \& Gollnick, 1988). If a human subject consumes a high-CHO diet, the R-value may approach 1.0. With a poor-CHO diet there is a greater reliance on fat and a corresponding decrease in the R-value, indicating decreased utilization of CHO.

Fat can only be used under aerobic conditions when oxidative muscle fibres like type I and type IIA are recruited. At rest the R-value in human subjects who have consumed a mixed diet is $0 \cdot 80-0 \cdot 85$ indicating that fat makes a contribution of about $50 \%$ to the total energy production. For an average person this amounts to about $4.5 \mathrm{~g}$ fat oxidized/ $\mathrm{h}$.

Bergström et al. (1967) showed that the glycogen content in muscles could be varied in individual subjects by introducing different diets after exhaustion of the glycogen store by hard exercise. The higher $\mathrm{R}$-values observed after the mixed and $\mathrm{CHO}$-rich diets 
indicate that the diet can influence the relative roles of fat and $\mathrm{CHO}$ as fuel during exercise. Furthermore, the correlation found between initial glycogen concentration and duration of work demonstrates that the individual's ability to sustain prolonged exercise is highly dependent on the glycogen content of the muscles, which in turn is dependent on the type of exercise. In this study the blood glucose concentration fell to extremely low values during prolonged severe exercise, indicating a relative depletion of glycogen in the liver in this situation and an increased uptake of blood glucose by the muscles.

Pagan et al. (1987) studied the effect of feeding diets containing different levels of $\mathrm{CHO}$, fat and protein to exercising standard-bred horses. The results showed a significantly higher R-value when the horses were fed on the control diet than when they were fed on either the high-protein or high-fat diets. During the high-speed test at $10 \mathrm{~m} / \mathrm{s}$ each horse utilized more glycogen and accumulated more blood lactate when fed on the control diet than when either the high-protein or high-fat diets were fed. During long slow work for almost $2 \mathrm{~h}$ at $5 \mathrm{~m} / \mathrm{s}$ pre-exercise liver glycogen was highest in the horses fed on the control diet. The post-exercise liver glycogen showed a $100 \%$ change with the high-protein and high-fat diets compared with the control diet, indicating a higher glucose uptake by the muscles when horses were fed on the low-CHO diets. It appears that the proportions of energy generated from $\mathrm{CHO}$ and fat during submaximal exercise can be influenced through dietary manipulations. This study also suggests that the concentration of muscle glycogen influences the proportion of energy generated from CHO during submaximal exercise in the horse.

When standard-bred horses were fed on a hay and oats diet $(6 \cdot 0 \mathrm{~kg}$ hay and $2.7 \mathrm{~kg}$ oats) in which barley syrup was substituted for oats in a change-over experiment, daily intakes $(\mathrm{g} / \mathrm{d})$ of starch and sugars respectively were 1134 and 157,924 and 517, 714 and 867,504 and 1227 for the diets containing $0,0.5,1.0$ and $1.5 \mathrm{~kg}$ barley syrup/d respectively. There were no significant effects of diet on plasma levels of glucose, lactate and insulin.

In an exercise-tolerance test there were no significant differences in R-value between diets at a trotting speed of 6,7 and $8 \mathrm{~m} / \mathrm{s}$. However, at $9 \mathrm{~m} / \mathrm{s}$ the R-value was significantly higher at the two highest levels of sugar intake (0.97 at the high sugar level; 0.95 at the low sugar level). Also in a submaximal test the R-value was higher at the two highest levels of sugar inclusion ( 0.83 at the high sugar level; 0.80 at the low sugar level; J. E. Lindberg, A. Jansson and A. Lindholm, unpublished results). The data from this experiment indicate a possible elevation in glucose utilization with an anaerobic workload at the highest level of glucose intake. The data also indicate a shift in substrate utilization from fat to glucose during an aerobic workload at the high levels of sugar intake. During prolonged light exercise there is a progressive increase in the amount of fat oxidized which in the untrained person may peak at about $50 \% V_{\mathrm{O}_{2} \max }$ and estimates of substrate flow through the muscle make it clear that the amounts of FFA available to the exercising muscle far exceed the energy requirements for exercise (Gollnick et al. 1981).

It has been demonstrated also that a close relationship exists between plasma concentration of FFA and the amount of fat being oxidized, as the uptake of FFA by muscle is dependent on FFA concentration in the blood. It has been shown that reliance on fat as a source of energy during submaximal exercise is greater after endurance training, with a lower R-value after training (Gollnick \& Saltin, 1988; Björntorp, 1991). 


\section{MUSCLE FIBRE CHARACTERISTICS}

In horses it has been shown that the oxidative capacity and capillarization of fibre types strongly influences the metabolic response to racing (Valberg \& Essén-Gustavsson, 1987). Within individuals, horses which possessed a high citrate synthase (EC 4.1.3.28; $\mathrm{CS}$ ) activity in type I fibres also possessed a relatively high CS activity in type II fibres. However, the magnitude of difference in CS activity between type IIA and type IIB fibres could vary greatly such that type IIB fibres possessed almost similar levels to type IIA fibres in some horses and half as much CS activity as type IIA fibres in other horses. The CS activity in type IIB fibres from one horse could be greater than that in the type I fibres in another horse.

Valberg \& Essén-Gustavsson (1987) also showed that the CP and ATP concentration in fibre pools post-race also varied greatly between horses. In type I fibre pools ATP and CP were not markedly decreased in any horse post-race, whereas low ATP levels were recorded in the type IIA and IIB fibre pools from a majority of horses after racing, with the lowest CP and ATP levels recorded in type IIB fibre pools. Horses which possessed a high oxidative capacity in fibre types appeared to maintain high ATP levels throughout the race.

Valberg et al. (1985) showed in a study on standard-bred trotters performing a standardized exercise-tolerance test on a treadmill that glycogen utilization in the gluteus medius muscle was negatively correlated to lactate accumulation $(r-0.89, P<0.05)$ and the trotting speed at a heart rate of 200 beats/min $(r-0.71, P<0.01)$. This study shows that horses which had a high percentage of type IIA fibres utilized less glycogen and produced less lactate than horses with a high percentage of type IIB fibres. The low oxidative capacity of the type IIB fibres makes them more dependent on glycolysis for energy production. Horses with a high percentage of oxidative type IIA fibres, on the other hand, may be able to spare glycogen either by oxidizing pyruvate rather than producing lactate or by utilizing other substrates such as triacylglycerols and FFA and glucose from the blood. Thus, it is possible that horses with a high percentage of low oxidative type IIB fibres have a lower capacity to utilize alternative metabolic pathways to glycolysis and, therefore, utilize more glycogen than horses with a high percentage of type IIA fibres while performing the same amount of work.

The reindeer (Rangifer tarandus) is a physically active animal and is exposed to daily endurance activity. It is interesting to note that reindeer muscle has a high oxidative potential in all three fibre types and still has a high percentage of type IIB fibres. Due to small muscle fibre areas in reindeers the number of capillaries per $\mathrm{mm}^{2}$ is as much as three to four times greater than that in human muscle, which facilitates the uptake of $\mathrm{O}_{2}$ and blood-borne substrates such as glucose and FFA. The glycogen and triacylglycerol stores indicate that both $\mathrm{CHO}$ and lipids are important for energy production. The low lactate dehydrogenase (EC 1.1.1.27; LDH) and triosephosphate dehydrogenase $(E C$ 1.2.1.9; TPDH) activities in reindeer muscle further indicate that energy is generated to the greatest extent through oxidative pathways in reindeer muscle (Essén-Gustavsson \& Rehbinder, 1985).

In inactive animals, such as the pig, the metabolic profile of the muscle is quite different, as pigs have about $85 \%$ low-oxidative type II muscle fibres.

It is well known that fat is the dominant substrate at rest and during low-intensity exercise when the metabolism of the muscle relies on aerobic metabolism. Little is known about the regulation of lipolysis within the muscle fibres during exercise. 


\section{EFFECT OF TRAINING}

Henriksson (1977), demonstrated that endurance training of muscle resulted in elevated lipid oxidation in the exercising limb. The higher fat combustion in trained muscles could be linked to elevated mitochondrial capacity induced by endurance training. It is possible that any increase in energy production that can occur by use of the lipid reserves of the body will conserve the glycogen stores, particularly those of the working muscles, and will increase exercise capacity (Saltin \& Astrand, 1993).

Essén-Gustavsson \& Lindholm (1985) showed that superior standard-bred race horses had smaller type II fibre areas and also possessed higher CS and 3-hydroxyacyl-CoA dehydrogenase ( $E C$ 1.1.1.35; HAD) activities in type I and type IIA fibres than inactive horses. After only 1 week of training standard-bred horses the oxidative capacity of the muscles increased, resulting in a glycogen-sparing effect caused by both a greater dependence on triacylglycerol for oxidation and on a higher ATP production from pyruvate oxidation.

Hurley et al. (1986) showed that the R-value is lower during exercise of the same intensity in the trained state compared with the untrained state, even though plasma FFA and glycerol levels are lower, suggesting reduced availability of plasma FFA. They suggested that the greater utilization of FFA in the trained state is fuelled by increased lipolysis of muscle triacylglycerols.

\section{CONCLUSIONS}

Fuel selection during exercise is dependent on a variety of factors and the intensity of exercise is a major determinant in fuel selection. The R-value is higher at high work intensities, indicating an increased relative contribution of $\mathrm{CHO}$ to total metabolism with increasing work intensity. Fibre type composition (I, IIA and IIB), enzyme capacity (CS, HAD, LDH and TPDH), fibre cross-sectional area and capillarization, i.e. the oxidative capacity of the muscle as well as the state of training are important characteristics for fuel selection during exercise. The source of fuel can be altered by diet, i.e. there is an increased R-value with a high-CHO diet and a decreased R-value with a poor-CHO diet. The concentration of muscle glycogen influences the proportion of energy generated from $\mathrm{CHO}$ during submaximal exercise in the horse. The blood-borne substrates glucose and FFA are important substrates during prolonged intense exercise. The magnitude of the local glycogen stores influences the uptake and use of the blood-borne substrate. There are still many questions about the regulation of substrate metabolism during exercise.

\section{REFERENCES}

Bangsbo, J., Graham, T. E., Kiens, B. \& Saltin, B. (1992). Elevated muscle glycogen and anaerobic energy production during exhaustive exercise in man. Journal of Physiology 451, 205-227.

Bergström, J., Hermansen, L., Hultman, H. \& Saltin, B. (1967). Diet, muscle glycogen and physical performance. Acta Physiologica Scandinavica 71, 140-150.

Björntorp, P. (1991). Importance of fat as a support nutrient for energy: metabolism of athletes. Journal of Sports Sciences 9, 71-76.

Costill, D. L., Thomason, H. \& Roberts, E. (1973). Fractional utilisation of the aerobic capacity during distance running. Medicine and Science in Sport and Exercise 5, 248-252.

Dohm, L. (1986). Protein as a fuel for endurance exercise. Exercise and Sport Science Reviews 143, $143-173$.

Essén-Gustavsson, B, Karlström, K. \& Lindholm, A. (1984). Fibre types, enzyme activities and substrate utilisation in skeletal muscles of horses competing in endurance rides. Equine Veterinary Journal 16, 197-202. 
Essén-Gustavsson, B. \& Lindholm, A. (1985). Muscle fibre characteristics of active and inactive standardbred horses. Equine Veterinary Journal 17, 434-438.

Essén-Gustavsson, B. \& Rehbinder, C. (1985). Skeletal muscle characteristics of reindeer (Rangifer tarandus). Comparative Biochemistry and Physiology 82A, 675-679.

Gollnick, P. D., Pernow, B., Essén, B., Jansson, E. \& Saltin, B. (1981). Availability of glycogen and plasma FFA for substrate utilization in leg muscle of man during exercise. Clinical Physiology 1, 27-42.

Gollnick, P. D. \& Saltin, B. (1988). Fuel for muscular exercise. Role of fat. In Exercise, Nutrition and Energy Metabolism, pp. 72-88 [E. S. Horton and R. L. Terjung, editors]. New York: Macmillan Publishing Corporation.

Gottlieb, M., Essén-Gustavsson, B., Lindholm, A. \& Persson, S. (1989). Effect of a draught loaded interval training programme on skeletal muscle in the horse. Journal of Applied Physiology 67, 570-577.

Henriksson, J. (1977). Training induced adaptation of skeletal muscle and metabolism during submaximal exercise. Acta Physiologica Scandinavica 270, 661-676.

Hermansen, L. \& Stensvold, J. (1972). Production and removal of lactate during exercise in man. Acta Physiologica Scandinavica 86, 191-201.

Hermansen, L. \& Vaage, O. (1977). Lactate disappearance and glycogen synthesis in human muscle after maximal exercise. American Journal of Physiology 233, E422-E429.

Hurley, B. F., Nemeth, P. M., Martin, W. H. III, Hagberg, J. M., Dalsky, G. P. \& Holloszy, J. O. (1986). Muscle triglyceride utilization during exercise: effect of training. Journal of Applied Physiology 60, $562-567$.

Lindholm, A., Bjerneld, H. \& Saltin, B. (1974). Glycogen depletion pattern in muscle fibres of trotting horses. Acta Physiologica Scandinavica 90, 475-484.

Nordheim, K. \& Völlestad, N. K. (1990). Glycogen and lactate metabolism during low-intensity exercise in man. Acta Physiologica Scandinavica 139, 475-484.

Pagan, J. D., Essén-Gustavsson, B., Lindholm, A. \& Thornton, J. (1987). The effect of dietary energy source on exercise performance in standardbred horses. In Equine Exercise Physiology, vol. 2, pp. 686-700 [J. R. Gillespie and N. E. Robinson, editors]. Davis, California: ICEEP Publications.

Pösö, A. R., Essén-Gustavsson, B. \& Persson, S. G. B. (1993). Metabolic response to standardised exercise test in standardbred trotters with red cell hypervolemia. Equine Veterinary Journal 25, 527-531.

Saltin, B. \& Åstrand, P.-O. (1993). Free fatty acids and exercise. American Journal of Clinical Nutrition 57 , $752 \mathrm{~S}-758 \mathrm{~S}$.

Saltin, B. \& Gollnick, P. D. (1988). Fuel for muscular exercise: Role of carbohydrate. In Exercise, Nutrition and Energy Metabolism, pp. 45-71 [E. S. Horton and R. L. Terjung, editors]. New York: Macmillan Publishing Corporation.

Valberg, S. \& Essén-Gustavsson, B. (1987). Metabolic response to racing determined in pools of type I, IIA and IIB fibers. In Equine Exercise Physiology, vol. 2, pp. 290-301 [J. R. Gillespie and N. E. Robinson, editors]. Davis, California: ICEEP Publications.

Valberg, S., Essén-Gustavsson, B., Lindholm, A. \& Persson, S. (1985). Energy metabolism in relation to skeletal muscle fibre properties during treadmill exercise. Equine Veterinary Journal 17, 439-444. 